\title{
CAUSATION IN SECTION 15 OF THE PROPERTY (RELATIONSHIPS) ACT 1976: ANALYSING THE NEW ZEALAND SUPREME COURT'S "WORKING ASSUMPTION"- Is IT REALLY WORKING?
}

\section{Tasneem Haradasa*}

\begin{abstract}
Scott v Williams concerned s 15 of the Property (Relationships) Act 1976. In situations of significant economic disparity post-separation, s 15 empowers courts to depart from the default rule of equal division of relationship property to compensate the disadvantaged partner. Causation is one of the jurisdictional hurdles. Only disparity "because of" the division of functions (DOF) is compensable. Thus far, courts have adopted a strict causation approach by placing a costly and often unattainable evidential burden on claimants. Consequently, compensation has been beyond reach for deserving claimants. Responding to this disquiet, Scott's majority propounded a "working assumption" of causation in relationships conducted along traditional lines, where one party assumes primary responsibility for domestic duties and the other for income-earning. In such situations, Scott's majority would assume causation at jurisdiction and attribute the entire disparity to the DOF when determining the quantum award. This article concludes that the working assumption is a positive development in terms of jurisdiction. However, unlike the majority, it argues that striking the correct balance between s 15's "because of" wording and broad policy rationale requires an apportionment of causes at quantum. Furthermore, Scott's "traditional lines" and "non-career partner" terminology creates unnecessary confusion and should be eschewed.
\end{abstract}

* Submitted for the LLB (Honours) Degree, Faculty of Law, Victoria University of Wellington, 2018. Awarded the Robert Orr McGechan Memorial Prize for the Best Student Work for the Victoria University of Wellington Law Review. I am extremely thankful to my supervisor, Professor Bill Atkin, for his wisdom, support and guidance. 


\section{INTRODUCTION}

In 2017, the New Zealand Supreme Court in Scott v Williams considered s 15 of the Property (Relationships) Act 1976 (PRA) for the first time. ${ }^{1}$ All five judges delivered judgments on s 15.

The PRA's default rule of equal division of relationship property was progressive when introduced. ${ }^{2}$ However, it soon became appreciated that this basis of "formal equality had failed somewhere, and that ... substantive equality ought to be considered". ${ }^{3}$ Section 15 , enacted in the PRA's 2001 reform, reflects this. ${ }^{4}$ It empowers courts to depart from equal division if satisfied that: ${ }^{5}$

after the ... relationship ends, [party B's] ... income and living standards ... are likely to be significantly higher than [party A's] ... because of the effects of the division of functions [(DOF)] within the ... relationship while the [parties] ... were living together.

A two-step analysis is required: (1) jurisdiction (when an award can be made); and (2) quantum (how much to award). One of the jurisdictional hurdles is causation. Only disparity because of the DOF is compensable. The DOF need not be the principal cause, ${ }^{6}$ or even a real and substantive cause. ${ }^{7}$ All jurisdiction requires is "a clear causal link"; 8 that the DOF is a cause of the disparity. ${ }^{9}$ Nevertheless, many courts have adopted a strict approach to causation. ${ }^{10}$ Consequent difficulties in establishing causation were identified as a key reason ${ }^{11}$ for widespread disappointment that s 15 "has not lived up to expectations". 12

Responding to this disquiet, Scott's majority on causation (Arnold and Glazebrook JJ and Elias $\mathrm{CJ}$ ) shifted from this strict approach and propounded a "working assumption" of causation in certain

1 Scott $v$ Williams [2017] NZSC 185, [2018] 1 NZLR 507.

2 See generally Bill Atkin Relationship Property in New Zealand (3rd ed, LexisNexis, Wellington, 2018) at 3.

$3 \quad M \vee B[2006] 3$ NZLR 660 (CA) at [215].

4 Property (Relationships) Amendment Act 2001, s 17.

5 Property (Relationships) Act 1976, s 15(1) (emphasis added).

$6 \quad M \vee B$, above n 3, at [201].

7 Atkin, above n 2, at 110 .

$8 X v X$ [Economic disparity] [2009] NZCA 399, [2010] 1 NZLR 601 at [108].

9 Atkin, above n 2, at 110 .

10 Law Commission Dividing relationship property - time for change? Te mātatoha rawa tokorau - Kua eke te wā? (NZLC IP41, 2017) at [18.60]; and Scott v Williams, above n 1, at [442] per William Young J.

11 Law Commission Dividing relationship property - time for change?, at [19.23].

12 Scott $v$ Williams, above n 1, at [279] per Arnold J. 
circumstances. This dictum was obiter as jurisdiction was conceded before the Supreme Court ${ }^{13}$ but it will be highly persuasive. ${ }^{14}$ Furthermore, causation is intertwined with quantum; an issue squarely before the Court.

Unfortunately, the judgments leave many unanswered questions. This article proposes some answers while critically analysing whether the assumption is a positive development. It concludes that the assumption is a positive development in respect of the jurisdictional causation hurdle, but argues that striking the correct balance between s 15's strict "because of" wording and broad policy rationale requires an apportionment of causes when determining compensable disparity at quantum. In this latter respect, it differs from Scott's majority. It also suggests that Scott's "traditional lines" and "noncareer partner" terminology should be eschewed. Therefore, it argues for the proposition that, where party A undertakes primary responsibility for domestic duties and party B for income-earning, there is an assumption that a causal link between the DOF and disparity exists. This is sufficient to satisfy the jurisdictional hurdle. The strength of this assumed causal link, as against other causes, should be apportioned and reflected in the quantum awarded.

This article does not analyse all of s 15's elements, resolve problems created by its conceptual inconsistencies ${ }^{15}$ and inadequate legislative process, ${ }^{16}$ or comment on all aspects of Scott. Its specific focus is the "working assumption". By unpacking the assumption and working through its rough edges, this article aims to help readers understand this judicial innovation and suggests how it could be improved.

It must be noted that the New Zealand Law Commission (NZLC) is currently undertaking a PRA reform project. ${ }^{17}$ Its Issues Paper, published two months before Scott, proposed three s 15 reform options. $^{18}$

- Option 1 was to retain s 15 but "lower the hurdles that ... [party] A must overcome". ${ }^{19}$ This included, inter alia, removing the requirement to establish causation and replacing it with "a

13 At [159] per Glazebrook J.

14 Atkin, above n 2, at 121

15 See Bill Atkin "Economic disparity - how did we end up with it? Has it been worth it?" (2007) 5 NZFLJ 299; and Joanna Miles "Dealing with Economic Disparity: An Analysis of Section 15 Property (Relationships) Act 1976" [2003] NZ Law Review 535.

16 See Ashley Varney "Divorcing Rhetoric from Reality: A Law Reform and Policy Perspective on Section 15 of the Property (Relationships) Act 1976" (LLB (Hons) Dissertation, Victoria University of Wellington, 2017).

17 Law Commission "Review of the Property (Relationships) Act 1976" < www.lawcom.govt.nz/our-projects>.

18 Law Commission Dividing relationship property - time for change?, above n 10, at [19.5].

19 At [19.5(a)]. 
rebuttable presumptive entitlement to compensation if there was financial inequality and a [DOF]". ${ }^{20}$

- Option 2 was to repeal s 15 and "address financial inequality in other PRA rules". ${ }^{21}$

- Option 3 was to replace s 15 with "financial reconciliation orders" intended to be a "hybrid" of s 15's compensatory provisions and the Family Proceedings Act 1980's (FPA) needs-based maintenance regime. ${ }^{22}$

Following a public consultation period, the NZLC published its Preferred Approach Paper (PAP) in November 2018. The PAP sets out a "package of reforms that [the NZLC] ... intend[s] to recommend to the Government in 2019". ${ }^{23}$ During the consultation, "[s]ubmitters were generally divided between favouring Option 1 and Option 3". ${ }^{24}$ Based on these results, the NZLC's current preferred approach is to repeal s 15 and the FPA's maintenance regime in favour of a Family Income Sharing Arrangement (FISA). ${ }^{25}$ The FISA regime reflects "a new way to share the economic advantages and disadvantages arising from a relationship or its end" 26 by providing a "limited entitlement to share future family income" in qualifying circumstances. ${ }^{27}$ The proposal is a "hybrid" of the NZLC's original Option 1 and Option $3^{28}$ and is set out below: ${ }^{29}$

[Party] A ... should be entitled to a FISA [(determined using a statutory formula)] in the following [qualifying] circumstances:

a. the partners have a child together; or

b. the relationship was 10 years or longer; or

c. during the relationship:

20 At [19.5(a)]. The "financial inequality" terminology reflects another New Zealand Law Commission (NZLC) proposal. The NZLC proposed "[r]eplacing the narrow concept of economic disparity with financial inequality", choosing to focus on disparities in income or other financial resources rather than on living standards: at [19.8]-[19.9].

21 At [19.5(b)].

22 At [19.5(c)].

23 Law Commission "Review of the Property (Relationships) Act 1976", above n 17.

24 Law Commission Review of the Property (Relationships) Act 1976: Preferred Approach - Te Arotake i te Property (Relationships) Act 1976: He Aronga i Mariu ai (NZLC IP44, 2018) at [5.34].

25 At [5.42].

26 At 99.

27 At [P18].

28 At [5.44].

29 At [P19]. 
(i) ... [party] A stopped, reduced or did not ever undertake paid work, took a lesser paying job or declined a promotion or other career advancement opportunity, in order to make contributions to the relationship; or

(ii) $\quad .$. [party] B was enabled to undertake training, education and/or other career sustaining or advancing opportunities due to the contributions of ... [party] A to the relationship.

However, critically analysing the s 15 judgments in Scott remains a worthwhile exercise. After all, the proposed FISA regime seemingly draws on Scott's causation analysis. If any of the FISA's qualifying circumstances apply, causation is to "be deemed" and the onus is to be reversed to party B to "show [that] the circumstances of the relationship did not result in economic advantage or disadvantage". ${ }^{30}$ This, like Scott's working assumption, is a presumption of causation and the FISA's qualifying circumstances reflect the concept of a DOF along "traditional lines" which was at the heart of the Scott decision. ${ }^{31}$ Furthermore the NZLC, in proposing a presumption of causation (albeit in the FISA context), was driven by the same desire to ameliorate "the difficulties experienced in [proving] causation under [s] $15^{\prime 32}$ as Scott's majority judges were when they propounded the working assumption. ${ }^{33}$ In any event, until and unless legislative reform occurs, s 15 remains and Scott will have significant implications for such cases whether litigated or negotiated in the shadow of the law.

\section{DECIPHERING THE WORKING ASSUMPTION}

\section{A Majority}

\section{When does it arise?}

The majority agreed that a rebuttable assumption of causation will arise in certain circumstances. What these circumstances are is unclear. There is support in all three judgments that causation is assumed if there was (1) significant disparity; and (2) a DOF. ${ }^{34}$ However, the real tenor of Arnold J's judgment was his repeated reference to role-divisions "along traditional lines" when formulating the assumption. ${ }^{35}$ On this formulation, causation is assumed if there was (1) significant disparity; (2) a

30 At [5.52] (italics omitted).

31 See Part II(A) below.

32 At [5.52].

33 See Parts IV-V below.

34 Scott $v$ Williams, above n 1, at [203], n 290 and [264] per Glazebrook J, [291] per Arnold J and [345] and [356] per Elias CJ.

35 At [293]-[294], [311] and [314] per Arnold J. 
DOF; and (3) the DOF was along traditional lines. This distinction is worth grappling with as the question of what qualifies as "traditional" can create confusion. ${ }^{36}$

Despite the uncertainty, it is likely Scott's assumption will be interpreted as requiring a relationship conducted along traditional lines ("traditional DOF relationship"). Arnold J provided the assumption's fullest exposition and his reasoning emphasised this requirement. ${ }^{37}$ Glazebrook $\mathrm{J}^{38}$ and Elias $\mathrm{CJ}^{39}$ also provide some support for this formulation. Furthermore, in expressing their disagreement, the minority conceptualised the assumption as arising in traditional DOF relationships. ${ }^{40}$ Thus it is important to understand what constitutes "traditional lines".

\section{Traditional lines}

This requirement does not require a traditional type of relationship (heterosexual marriage). Rather, it requires a traditional DOF. ${ }^{41}$ Scott interprets a traditional DOF as "one party ... assuming the primary responsibility for home-making and child-care ... and the other assuming responsibility for income-earning". ${ }^{42}$ Past cases adopted similar interpretations. ${ }^{43}$ This requirement's parameters are analysed in Part VI.

\section{A legal presumption}

The "working assumption" terminology was likely used as a synonym for a legal presumption. Scott's language of rebutting, ${ }^{44}$ negativing ${ }^{45}$ and displacing ${ }^{46}$ the assumption is evocative of other legal contexts containing rebuttable presumptions. ${ }^{47}$ Glazebrook $\mathrm{J}$ further reinforced this by using the

36 At [382] per O'Regan J; and Atkin, above n 2, at 111. See also Part VI below.

37 See for example Scott $v$ Williams, above n 1, at [293]-[294], [311] and [314] per Arnold J.

38 At [203], n 290 and [204], n 292 per Glazebrook J, citing [293] and [307]-[323] per Arnold J.

39 At [356] per Elias CJ agreeing with Arnold J's broad causation approach.

40 At [385] per O'Regan J and [444] per William Young J.

41 At [293] per Arnold J.

42 At [282] per Arnold J, [264] per Glazebrook J and [331] per Elias CJ agreeing with [264] per Glazebrook J.

43 See for example CRH v GDH DC Auckland FAM-2007-004-1129, 24 December 2008 at [1]; and Jack v Jack [2014] NZHC 1495 at [52].

44 Scott $v$ Williams, above $\mathrm{n}$ 1, at [264] per Glazebrook J.

45 At [293] and [324] per Arnold J.

46 At [323] per Arnold J.

47 Atkin, above n 2, at 111. 
terms interchangeably. ${ }^{48}$ Creating a rebuttable presumption has implications for matters of proof. Part $\mathrm{V}(\mathrm{C})$ explores these implications.

\section{B Minority}

Analysing O'Regan and William Young JJ's dissents require understanding the assumption's twofold relevance to jurisdiction (assuming causation to satisfy the jurisdictional hurdle); and quantum (the extent of causation assumed in determining compensable disparity).

As discussed below, the impetus for the majority's assumption and the NZLC's proposals was the strict causation approach, which undermined s 15 's spirit. ${ }^{49}$ Like the majority and NZLC, one senses O'Regan J was not particularly pleased with the pre-Scott direction of causation. ${ }^{50} \mathrm{In}$ fact, he believed that the NZLC's Option 1 provided a "good case for reform". ${ }^{51}$ However for him, the solution was legislative reform to remove the "because of" wording rather than a judge-made assumption. ${ }^{52} \mathrm{He}$ considered assumptions "contrary to [s 15's] ... current ['because of'] wording". ${ }^{53}$ William Young J indicated similar disapproval. ${ }^{54}$

The minority's more vociferous critique concerned the assumption's relevance to quantum. The starting point of the Supreme Court's new disparity-based quantum methodology, is "the extent of the disparity resulting from the [DOF]". ${ }^{55}$ The majority believed that where the assumption was not displaced, "the [entire] disparity should be attribut[ed] to the [DOF]" ("no-apportionment approach"). ${ }^{56}$ The minority considered this contrary to s 15 's wording that only disparity caused by

48 Scott $v$ Williams, above n 1, at [204] and [204], n 293 per Glazebrook J.

49 See Parts IV-V below. See also Law Commission Review of the Property (Relationships) Act 1976: Preferred Approach, above n 24, at [5.52] where the NZLC cite the "difficulties experienced in [proving] causation under [s] 15" as justifying what is essentially a presumption of causation in the proposed FISA regime.

50 See Scott $v$ Williams, above n 1, at [380]-[381] per O'Regan J.

51 At [380] per O'Regan J.

52 At [380] per O'Regan J.

53 At [382] per O'Regan J.

54 At [446] per William Young J.

55 At [326(a)] per Arnold J.

56 At [326(a)], n 420 per Arnold J, [204] and [264] per Glazebrook J and [331] per Elias CJ agreeing with [264] per Glazebrook J. See also at [444(c)] per William Young J conceptualising no-apportionment as the majority's approach. 
the DOF is compensable. ${ }^{57}$ As later discussed, this article agrees with the minority's apportionment reasoning. 58

\section{THE VALIDITY OF THE WORKING ASSUMPTION}

Arnold J validated his assumption of causation based on three underlying assumptions. ${ }^{59}$ He said it should be assumed that a traditional DOF "(a) was for the benefit of both parties; (b) restricted [party A's] ... income-earning ability; and (c) enhanced [party B's] ... earning ability". ${ }^{60}$

Assumption (a) endorses what is sometimes called $X \vee X$ [Economic disparity]'s "presumption of causation". ${ }^{61}$ Strictly speaking, this simply presumes the DOF was a mutual choice. ${ }^{62}$ Through assumptions (b) and (c) Scott goes further than $X \vee X$ and assumes the causation hurdle itself is satisfied. Assumptions (b) and (c) reflect the common bases for s 15 claims before Scott, founded on party A's restricted (or diminished) income-earning ability, and/or party B's enhanced income-earning ability, because of the DOF. ${ }^{63}$

Arnold J noted that assumptions (b) and (c) reflect international research. ${ }^{64}$ It is beyond this article's scope to comprehensively explore the socio-economic evidence-based justifications of assumptions (b) and (c). International research on post-separation disparity is extensive. ${ }^{65}$ A brief

57 At [384]-[385] per O'Regan J and [446] and [449]-[450] per William Young J.

58 See Part V(B) below.

59 At [311] per Arnold J.

60 At [311] per Arnold J.

61 Mark Henaghan and others Family Law in New Zealand (18th ed, LexisNexis, Wellington, 2017) at 1106.

62 At 1106

63 Scott $v$ Williams, above n 1, at [290] per Arnold J.

64 At [311]-[313] per Arnold J.

65 See for example Hans-Jürgen Andreß and others "The Economic Consequences of Partnership Dissolution A Comparative Analysis of Panel Studies from Belgium, Germany, Great Britain, Italy, and Sweden" (2006) 22 Eur Sociol Rev 533, as cited in Law Commission Relationships and Families in Contemporary New Zealand: He Hononga Tangata, He Hononga Whānau I Aotearoa O Nāianei (NZLC SP22, 2017) at 60, n 399; David de Vaus and others The economic consequences of divorce in six OECD countries (Australian Institute of Family Studies, Research Report No 31, March 2015); AR Poortman "Sex differences in the Economic Consequences of Separation: A Panel Study of the Netherlands" (2000) 16 Eur Sociol Rev 367, as cited in Michael John Fletcher "An investigation into aspects of the economic consequences of marital separation among New Zealand parents" (PhD Thesis, Auckland University of Technology, 2017) at 70; and Pamela J Smock "Gender and the Short-Run Economic Consequences of Marital Disruption" (1994) 73 Social Forces 243 
discussion is sufficient, drawing primarily on the NZLC's ${ }^{66}$ and Green's ${ }^{67}$ recent and extensive analyses of these socio-economic trends. Arnold J utilised both analyses. ${ }^{68}$

Internationally, and in New Zealand, women take longer than men to recover economically postseparation. ${ }^{69}$ International studies identify the traditional DOF between paid and unpaid work as contributing to this disparity ${ }^{70}$ with one study concluding that "hours worked per week prior to separation can explain approximately 41 [per cent]" of the gender pay-gap post-separation. ${ }^{71}$ Additionally, extensive socio-economic research suggests that marriage enhances male earning capacity. ${ }^{72}$ The reason for this is that these men "are able to [earn more by] specialis[ing] in making money" without being burdened by domestic duties undertaken by their wives. ${ }^{73}$ In New Zealand, despite increasing female workforce participation, men still spend significantly more time than women in paid employment, while women spend almost twice as much time as men on domestic work. ${ }^{74}$ Thus to the extent that these international studies can be transposed in a New Zealand context, the statistics suggest assumptions (b) and (c) are valid.

The reliance on this research could be criticised as it primarily speaks in the context of a heterosexual marriage with a housewife and breadwinning husband. After all, s 15 does not preclude claims from male, de facto or civil union partners. However, this research remains applicable because New Zealand's society is still such that most s 15 cases have involved, and in the foreseeable future will continue to involve, female claimants in heterosexual marriages. ${ }^{75}$

Economists have also doubted the usefulness of blanket statistics as "their high degree of aggregation [can] hid[e] large differences in the experiences of individual divorced men and women". ${ }^{76}$ However, these concerns do not invalidate the working assumption. A presumption's

66 Law Commission Relationships and Families in Contemporary New Zealand, above n 65.

67 Claire Green "The impact of section 15 of the Property (Relationships) Act 1976 on the vexing problem of economic disparity" (PhD Thesis, University of Otago, 2013).

68 Scott $v$ Williams, above $\mathrm{n}$ 1, at [312] per Arnold J.

69 Law Commission Relationships and Families in Contemporary New Zealand, above n 65, at 60.

70 At 60 .

71 Fletcher, above n 65, at 70, citing Poortman, above n 65.

72 Green, above $n$ 67, at 298.

73 At 76 (footnote omitted).

74 Law Commission Relationships and Families in Contemporary New Zealand, above n 65, at 44.

75 See generally Law Commission Relationships and Families in Contemporary New Zealand, above n 65, at 44 and 60 .

76 Susan St John "Income expectations of men and women after separation" (paper presented to the Family Law Conference, Wellington, October 1995) at 23, as cited in Atkin, above n 2, at 101. 
function is to "reflec[t] what is regarded as most convenient in terms of bringing an issue to proof". ${ }^{77}$ Its contents "reflect what was probably [likely] ... in the circumstances prevailing at the time of [its] ... articulation"78 and it simply allows courts to "draw a particular inference from a particular fact, ... unless ... disproved". ${ }^{79}$ Given s 15 only requires the DOF be a cause, rather than a principal, or real and substantive cause, the socio-economic research indicates that the assumption is not unfounded. In the usual traditional DOF relationship, some causal link is likely due to the DOF restricting party A's, and/or enhancing party B's, income-earning capacity. If specific relationships deviate from this likely position, the assumption can be rebutted. However in the usual situation, the assumption removes party A's need to positively prove causation, which has hitherto proved difficult. As explored below, to the extent that this puts compensation within reach for deserving claimants, the assumption is a positive development. ${ }^{80}$

Furthermore, validating the working assumption based on underlying assumptions of restricted (or diminished), and enhanced, earning capacity may appear incongruous given the Supreme Court criticised the "diminution" and "enhancement" categories at quantum. ${ }^{81}$ The criticism was that these categories lead to awards compensating party A's loss, or redistributing party B's enhancement, without compensating for relative disparity as s 15 requires. ${ }^{82}$ However in validating what underlies the assumption of causation, this article, like the majority, uses the "restricted" and "enhancement" terminology. ${ }^{83}$ This provides a useful mechanism to understand why causation can be assumed, as disparity caused by the DOF is necessarily because the DOF restricted party A's earning capacity and/or enhanced party B's. Because the socio-economic research confirms that traditional DOF relationships do have this effect, jurisdictional causation can safely be assumed. It is simply that quantum no longer turns on precise diminution or enhancement amounts.

77 CEF Rickett "The Classification of Trusts" (1999) 18 NZULR 305 at 316.

78 At 316 .

79 Courtenay Ilbert in Encyclopaedia Britannica (11th ed, 1910) vol 10 Evidence at 15, as cited in Nicholas Rescher Presumption and the Practices of Tentative Cognition (Cambridge University Press, Cambridge, 2006) at 2.

80 See Parts IV-V(A)(1) below.

81 Scott $v$ Williams, above n 1, at [347]-[352] and [357]-[358] per Elias CJ. See also at [197] and [204] per Glazebrook J, [293]-[294], [323] and [326] per Arnold J and [385] per O'Regan J.

82 At [347] per Elias CJ.

83 See at [203] per Glazebrook J, [311] per Arnold J and [345] per Elias CJ. 


\section{THE IMPETUS FOR THE WORKING ASSUMPTION}

Before Scott, "a few cases" took a broad approach to causation using reasoning similar to that of Scott's majority. ${ }^{84}$ However, a strict approach was "usually" adopted, ${ }^{85}$ imposing a high evidential burden on party A by emphasising a "but for" causal link ${ }^{86}$ and "requir[ing hard] evidence of [party A's] loss of earning ability ... or enhancement of ... [party] B's earning capacity". ${ }^{87}$

Commentators, ${ }^{88}$ policy advisers ${ }^{89}$ and practitioners ${ }^{90}$ have criticised this overly restrictive approach. The NZLC identified difficulties in establishing causation as a "key issue undermining ... [s 15's] effectiveness", 91 estimating that 20 per cent of cases failed at causation. ${ }^{92}$ Garland's earlier review of 60 cases found 48.3 per cent failed at the causation hurdle. ${ }^{93}$ These statistics may partly be explained by unmeritorious cases where disparities were caused by non-function related causes. However, analysis of past case law suggests that deserving claimants have been barred by the strict, "unrealistically narrow approach". ${ }^{94}$ These cases provide the impetus for the assumption.

As a general criticism, the strict approach incentivises speculative, costly and unedifying evidence to be led. ${ }^{95}$ This article identifies and explores two specific categories that illustrate these general issues and pose policy issues of their own. As later argued, the assumption's ability to provide a solution makes it a positive development. ${ }^{96}$

84 Law Commission Dividing relationship property - time for change?, above n 10, at [18.60].

85 Scott $v$ Williams, above $\mathrm{n}$ 1, at [442] per William Young J.

$86 M v B$, above $\mathrm{n}$ 3, at [201] per William Young P.

87 Law Commission Dividing relationship property - time for change?, above n 10, at [18.60].

88 See Nicola Peart and Patrick Mahoney (eds) Brookers Family Law - Family Property (looseleaf ed, Thomson Reuters) at [PR15.01]; and Fae Garland "Section 15 Property (Relationships) Act 1976: Compensation, Substantive Equality and Empirical Realities" [2014] NZ Law Review 355 at 363-367.

89 See Law Commission Dividing relationship property - time for change?, above n 10, at [18.69] and [19.23].

90 See Green, above n 67, at 83, n 267.

91 Law Commission Dividing relationship property - time for change?, above n 10, at [19.23].

92 At [18.44].

93 Garland, above n 88, at 359.

94 Scott $v$ Williams, above $\mathrm{n}$ 1, at [307] per Arnold J.

95 At [309]-[310] per Arnold J.

96 See Part IV(C) below. 


\section{A First Problematic Category}

The strict approach is problematic where party A "ha[s no] serious career prospects at all" either because: (1) party A's work before the DOF was low-skilled; or (2) the DOF occurred before party A had the chance to begin a career. ${ }^{97}$ In Garland's review, 37.93 per cent of unsuccessful causation cases stumbled on this point. ${ }^{98}$

The difficulty arises from party A's high evidential burden under the strict approach. Courts have required "detailed evidence about the availability of positions ... which [party A] ... was unable, for a function based reason, to attain". ${ }^{99}$ Many claims fail because of "a paucity of evidence about [likely] career paths [and] current opportunities". ${ }^{100}$ However, such evidence is inherently speculative and involves guesswork. ${ }^{101}$ Even claimants with prior careers face difficulties in accurately predicting their hypothetical "but for" position on a career pay-scale, but experts can be employed to make educated guesses. For such claimants this evidential burden is costly but at least attainable. For claimants without prior careers, or with low-skilled jobs, the evidential burden is likely unattainable as even experts cannot predict "but for" career paths in such situations.

Where party A's prior work was low-skilled, the tendency is for low income-earning capacity post-separation to "be attributed to ... [party A's] lack of skill, training or ... ambition" instead of the DOF. ${ }^{102}$ In PEL $v$ FFB, PEL was university educated but her pre-relationship work was lowskilled. ${ }^{103}$ Because she "ha[d] not developed prior to ... [the DOF] even the beginning phases of a career", the court lacked "confidence ... [to] establish a but for income". ${ }^{104}$

97 Atkin, above n 2, at 119.

98 Garland, above n 88, at 365. See also Joanna Miles "Financial Provision and Property Division on Relationship Breakdown: A Theoretical Analysis of the New Zealand Legislation" (2004) 21 NZULR 268 at 280, n 54.

99 Walker $v$ Walker [2006] NZFLR 768 (HC) at [116] (emphasis added).

100 At [115]. See also Law Commission Dividing relationship property - time for change?, above n 10, at [18.66], n 93 for examples of cases failing at causation due to a lack of evidence of an alternative career.

101 Scott v Williams, above n 1, at [309] per Arnold J; and Green, above n 67, at 331.

102 Garland, above n 88, at 365, citing Douglas v Douglas [2013] NZHC 3022, [2014] NZFLR 235.

103 PEL v FFB [2012] NZFC 9534. Unusual circumstances meant the parties' living standards were not disparate, despite FFB's significantly higher income. For this article's causation focus, let us assume significant disparity was established.

104 At $[70(\mathrm{c})]$ 
Additionally, in these situations the strict approach's emphasis on a "hard"105 causal link incentivises party B to lead unedifying evidence minimising party A's skills. ${ }^{106}$ Party B argues that this lack of skill was responsible for party A's low income-earning capacity rather than the DOF. ${ }^{107}$ For example, PEL argued she would have been an associate professor absent the DOF. ${ }^{108}$ In response, FFB engaged expert evidence pointing to PEL's "grades, lack of work experience and zero publications" to argue that "she ... [could not] have got through [even] ... the first hurdle of obtaining entry into a Masters programme" which was a prerequisite for associate professorship. ${ }^{109}$ Such invidious inquiries exacerbate existing tensions in a break-up context and are "antithetical to important [PRA] values". 110

$P E L$ also illustrates the problematic "all or nothing" mentality created by strict causation. As later discussed, strict causation goes hand in hand with $X v X$ 's quantum methodology that quantifies compensation based on the differential between party A's actual and "but for" income. ${ }^{111}$ If "but for" income determines compensation, party A is incentivised to pitch their "but for" income as high as possible and sometimes unrealistically so. In trying for it "all", party A often ends up with 'nothing' even though "something" was deserved. For example, PEL argued that "but for" the DOF she would have been an associate professor; no doubt with the motivation of maximising her "but for" income. Based on her argument, the question became: did the DOF cause PEL's lost opportunity to become an associate professor? The Court unhesitatingly answered negatively given her inadequate qualifications for the role. That answer is not criticised. However, it was not the right question. The jurisdictional question should be whether a causal link between the DOF and disparity exists. In undertaking full-time domestic duties while FFB worked full-time, surely PEL's earning capacity was restricted to some extent, or at least FFB's was enhanced. This may not explain the entire disparity but jurisdictional causation does not require the DOF to be the sole or principal cause. Common sense and socio-economic research indicate that it explains at least some of the disparity, which is sufficient to say that a causal link, and hence jurisdiction, exists. Rejecting the possibility of any causal link, and hence any compensation, due to an evidentially unsubstantiated "but for" income denies PEL her deserved compensation for even that small amount of disparity attributable to the DOF. The

105 Scott $v$ Williams, above $\mathrm{n}$ 1, at [384] per O'Regan J.

106 At [310] per Arnold J.

107 At [309] per Arnold J.

108 PEL v FFB, above n 103, at [65].

109 At [67].

110 Scott $v$ Williams, above $\mathrm{n} 1$, at [310] per Arnold J.

111 See Part V(A)(2) below. 
assumption coupled with Scott's disparity-based quantum approach eschews the "but for" argument's relevance, making this problematic "all or nothing" approach less likely.

$C R H \vee G D H$ illustrates the strict approach's problematic application when party A had no career before the DOF. ${ }^{112}$ The parties married when CRH fell pregnant aged 16. They had three children. During the 34-year marriage, CRH was a "career wife", and GDH the "breadwinner throughout". ${ }^{113}$ CRH failed at causation, inter alia, ${ }^{114}$ because: ${ }^{115}$

[s]he had never developed a career in her teenage years because she had insufficient time. It [was] therefore very difficult for her to show that there [was] a detrimental effect on a career development because she did not have one in which to develop.

For claimants like $\mathrm{CRH}$, the strict approach requiring evidence of a "but for" income works an injustice. ${ }^{116}$ Nathan $v$ Nathan held a lack of pre-relationship "qualifications or employment history ... does not disquali[fy]" party A's claim. ${ }^{117}$ However, it is difficult to see party A succeeding under strict causation. There is no "but for" abandoned career to point to and courts have been unwilling "to speculate" in such circumstances. ${ }^{118}$ Thus a lack of pre-relationship employment is disqualifying in reality, albeit not legally.

Arnold $\mathrm{J}$ said it was undisputable that claimants like CRH deserve compensation. ${ }^{119}$ This is correct given Nathan's dictum. Additionally, the legislative history suggests s 15 sought to ameliorate this type of mischief. ${ }^{120}$ For example, the 1988 Royal Commission on Social Policy lamented that "[t]he loss of, or failure to gain, a career [was] not compensable" before s $15 .{ }^{121}$ Yet the strict

$112 C R H \vee G D H$, above n 43

113 At [1].

114 CRH filed proceedings 13 years after separation. The Court suggested that by then the DOF's effects were a spent force and CRH's earning capacity was caused by her personal post-separation decision not to seek fulltime employment or training. Nevertheless, the Court's reasoning indicates causation would have failed independent of the timing issue, making this case a useful illustration of the strict approach's problematic application.

$115 C R H \vee G D H$, above n 43, at [49].

116 See Scott $v$ Williams, above n 1, at [307] per Arnold J.

117 Nathan $v$ Nathan [2004] NZFLR 942 (FC) at [100].

118 LD MCL v JP MCL FC Christchurch FAM-2007-009-504, 28 November 2008 at [59].

119 Scott $v$ Williams, above n 1, at [307] per Arnold J.

120 Green, above n 67, at 205.

121 Ivor Richardson and others Report of the Royal Commission on Social Policy: Te Kōmihana A Te Karauna Mō Ngā Āhuatanga-Ā-Iwi (Government Printer, April 1988) vol 4 at 219 (emphasis added). 
approach deprives such claimants. Furthermore, the strict approach's reluctance to find causation in enhancement claims, discussed below, accentuates such claimants' vulnerabilities. ${ }^{122}$

\section{B Second Problematic Category}

Commentators have criticised courts for overlooking enhancement claims. ${ }^{123}$ Analysis of past cases indicates that the rarity of successful enhancement claims is largely attributable to a reluctance to find causation, and to quantification difficulties. ${ }^{124}$

That one's innate talent, qualifications and work ethic help determine earning capacity is uncontroversial. Rather, party A argues that party B's ability to develop talent, receive qualifications and possess such a work ethic is because party A's domestic role "freed up" party B to do so. ${ }^{125}$ However, under the strict approach the tendency is to view party B's natural attributes alone as explaining the disparity ${ }^{126}$ absent "factual evidence of [the] degree or amount [of enhancement]"127 or "some comparative evidence ... to enable ... [party B's] earnings pattern to be assessed against ... other[s in similar professions]". ${ }^{128}$ Adducing such evidence often requires costly expert witnesses to attribute numerical values to party A's non-financial contributions. Even then, success is not guaranteed as even experts struggle to find foundations for their figures. For example, in Scott an expert gave evidence that the DOF enhanced Williams' annual income by $\$ 50,000$ but accepted in cross-examination that this was merely a "judgement". ${ }^{129}$ The High Court ${ }^{130}$ and Court of Appeal ${ }^{131}$ rejected causation on the enhancement claim due to this lack of evidential foundation.

122 See Part IV(B) below.

123 See Mark Henaghan "What can you do about inequality post separation and post division?" (paper presented to New Zealand Law Society Relationship Property Intensive, August 2010) at 101; Green, above n 67, at 309; Mark Henaghan and Nicola Peart "Relationship Property Appeals in the New Zealand Court of Appeal 1958-2008: The Elusiveness of Equality" in Rick Bigwood (ed) The Permanent New Zealand Court of Appeal: Essays on the First 50 Years (Hart Publishing, Oxford, 2009) 99 at 101; and Susannah Shaw "Disparity in Jack v Jack: Judicial Overreach or a Just Result at Long Last?" (2014) 45 VUWLR 535 at 537, nn 11, 12 and 13.

124 Law Commission Dividing relationship property - time for change?, above n 10, at [18.52]; and Scott v Williams, above n 1, at [203] per Glazebrook J.

125 Law Commission Dividing relationship property - time for change?, above n 10, at [18.55].

126 Varney, above n 16, at 15.

127 P v R FC Auckland FAM-2004-004-3234, 30 November 2006 at [47].

$128 P \vee P[2005]$ NZFLR 689 (HC) at [61].

129 Scott $v$ Williams [2016] NZCA 356, [2016] NZFLR 499 [Scott v Williams (CA)] at [109].

130 Williams $v$ Scott [2014] NZHC 2547, [2015] NZFLR 355 [Williams v Scott (HC)] at [167].

131 Scott $v$ Williams (CA), above n 129, at [109]. 
This is problematic because research and common sense indicate that by undertaking domestic duties, party A frees party B to specialise in money making. ${ }^{132}$ However, absent evidence of the degree or amount of enhancement, party A's role is characterised as "merely permissive" rather than "truly causative". ${ }^{133}$ This was so even where party A undertook day-to-day childcare, while party B worked long hours, took unscheduled trips and spent 70 days a year overseas. ${ }^{134}$ Similarly in $C R H$, GDH's earning capacity was attributed to the "very long hours" he worked. ${ }^{135}$ When one remembers that the parties married young when CRH fell pregnant, consequently having two more children, then surely at least part of the reason why GDH could work long hours was because CRH undertook childcare. This was especially pertinent as both parties entered the relationship with no qualifications. GDH undertook an apprenticeship during the marriage, working as an electrician thereafter. ${ }^{136}$ Ostensibly CRH could have completed the same apprenticeship, done the same work and had a similar earning capacity if she did not have to undertake full-time domestic duties.

Additionally, "problematic dicta" concerning the "nanny argument" have emerged from the "but for" test's application. ${ }^{137}$ The "but for" focus allows the argument that the DOF did not cause party B's enhanced earning capacity because "but for" party A undertaking domestic duties, party B would still have devoted as much time and effort towards their career because a nanny would have been employed to undertake domestic duties. ${ }^{138}$ This approach is flawed. It degrades party A's contribution to that of a substitute service, thus flouting the PRA's "bedrock" equality of contribution principle. ${ }^{139}$ It favours "individualism", attributing party B's high earning capacity solely to party B's individual character, ${ }^{140}$ consequently undermining the PRA's underlying premise of relationships being joint enterprises. ${ }^{141}$ Additionally, focusing on what could have occurred is misplaced given $X v X$ 's wellsettled presumption of mutual decision-making. ${ }^{142}$ Perhaps a nanny could have been employed. However for whatever reason, in a traditional DOF relationship, the parties chose not to employ a

132 See Part III above.

133 DJE v TJAE [2012] NZFC 830 at [140].

$134 P \vee R$, above $\mathrm{n} 127$, at [47] and [50].

$135 C R H \vee G D H$, above n 43, at [51].

136 At [1].

137 Shaw, above n 123, at 538

138 See $M v B$, above n 3, at [201]; and JES v JBC [2007] NZFLR 472 (HC) at [32].

139 See Property (Relationships) Act, ss $1 \mathrm{M}(\mathrm{b}), 1 \mathrm{~N}(\mathrm{~b})$ and 18(2); and Scott $v$ Williams, above n 1, at [310] and [324] per Arnold J.

140 Green, above n 67, at 309.

141 Henaghan, above n 123, at 101.

142 Jack v Jack, above n 43, at [51]. 
nanny instead deciding party A would undertake such work. ${ }^{143}$ The focus must be on the relationship's realities and its actual consequences.

\section{Solution}

Under Scott, causation would be assumed, subject to rebuttal, in traditional DOF relationships such as $C R H^{144}$ and PEL. In fact, because Scott discards "diminution" and "enhancement" awards at quantum, the two problematic categories aforementioned are eliminated altogether. ${ }^{145}$ Scott's new quantum methodology and assumption rely on each other for workability. ${ }^{146}$ Because separate awards are no longer made for diminution and enhancement, separate causative inquiries into diminution and enhancement are unnecessary. It is no longer harder for claimants without prior careers or with lowskilled jobs to succeed, or for enhancement claims to be established. Rather, in traditional DOF relationships common sense and socio-economic research allow a sensible assumption that the DOF restricted party A's earning capacity and enhanced party B's earning capacity and hence that a causal link between the DOF and disparity exists. Consequently, a single award compensating this disparity can be made.

Although not every case has employed the strict approach in the aforementioned scenarios, ${ }^{147}$ it has been the common approach. ${ }^{148}$ The assumption eliminates the potential for inconsistency and better achieves s 15's policy rationale by ensuring an unrealistically strict approach does not deprive deserving claimants.

\section{STRIKING THE CORRECT BALANCE}

Green explained the causation dilemma as: ${ }^{149}$

the inherent difficulty ... in achieving the correct balance between being unduly restrictive, rarely finding

$\ldots$ disparity was as a result of the ... [DOF], to lowering the ... bar so that the causation test is effectively

meaningless.

For the reasons discussed below, amalgamating the majority's jurisdictional reasoning and the minority's apportionment reasoning best strikes this balance.

143 Shaw, above n 123, at 539.

144 Rebuttal may be successful due to reasons discussed at n 114 .

145 Scott $v$ Williams, above $\mathrm{n}$, at [323] per Arnold J.

146 See Part V(A)(2) below.

147 See for example $H v H$ HC Nelson CIV-2006-442-313, 20 October 2006 at [25].

148 Law Commission Dividing relationship property - time for change?, above n 10, at [18.60].

149 Green, above n 67, at 55. See also Scott v Williams, above n 1, at [384] per O'Regan J. 


\section{A Jurisdiction}

In terms of jurisdiction, Green's statement reflects the choice between the strict approach and the broad working assumption approach. The assumption's ability to resolve issues caused by the strict approach as discussed in Part IV(C), alongside the further reasons discussed below, make the majority's assumption the better choice at jurisdiction.

\section{Purpose of causation: text versus policy}

Resolving the dilemma requires analysing why the causation requirement exists. The difficulty is that its purpose is unclear, with incongruity between s 15's text and policy rationale. ${ }^{150}$

The strict "but for" requirement is certainly an available, if not the most obvious, interpretation of s 15 's "because of" wording. ${ }^{151}$ However in causation law, the "but for" test's key limitation is its potential non-application where multiple sufficient causes exist. ${ }^{152}$ In s 15 cases, multiple causes are almost invariably at play making a "but for" test unworkable. After all, a "person's income does not come down to any one thing but ... depends on multiple factors". 153 These factors include luck, talent and work ethic, but also the DOF. Indeed this is recognised even in cases propounding the "but for" test as it is well-settled that the DOF need not be the sole cause of the disparity. ${ }^{154}$ Consider a situation where "disparity is due in equal measure to ... [the DOF] and [party B's] ... innate skills". ${ }^{155}$ Jurisdiction should exist; party A is entitled to some compensation as there is a causal link between the DOF and disparity. However, "it is not true of either cause that but for its occurrence, ... [a disparity] would not have transpired", making neither the DOF nor party B's innate skills a factual cause under the "but for" test. ${ }^{156}$

Furthermore, as discussed, the strict approach leads to outcomes antithetical to s 15's policy rationale. ${ }^{157}$ For example, a $C R H$-type claimant has no obvious "but for" career path to point to. ${ }^{158}$

150 Green, above n 67, at 205.

151 At 205

152 See Steven Yannoulidis "Causation in the Law of Negligence" (2001) 27 Mon LR 319 at 320; and David Jackson "Some Thoughts on Causation and Loss of a Valuable Commercial Opportunity" (paper presented to TC Beirne School of Law Current Legal Issues Seminar 2: Causation and Loss of Opportunity, Queensland, July 2017) at [25]-[26] and [30]-[31].

153 Green, above n 67, at 55 .

$154 M v B$, above n 3, at [201].

155 Scott $v$ Williams, above n 1, at [446] per William Young J.

156 Yannoulidis, above n 152, at 320 .

157 See Part IV above.

158 Scott $v$ Williams, above n 1, at [307] per Arnold J. 
Yet various legislative materials recognised the lack of a career option as "a significant economic handicap" requiring rectification via s $15 .{ }^{159}$ Additionally, a "but for" approach justifies the nanny argument. ${ }^{160}$ Yet such arguments are unedifying, contrary to the equality of contribution principle and misplaced given the unattractive proposition of courts substituting retrospective judgments of how relationships should have been structured. ${ }^{161}$

Therefore, although s 15's text points to a "but for" test, theoretically it is unworkable where multiple sufficient causes exist. Practically, its implementation creates results contrary to the PRA's spirit. Yet the judiciary cannot ignore the causation requirement. Such change is for Parliament.

However, arguably what courts can and ought to do, in the context of social, non-technical legislation ${ }^{162}$ is discussed in Elias CJ's extra-judicial comments. ${ }^{163}$ She queried "whether in social legislation ... it is appropriate for courts ... to refine too much on the terms of the statute", 164 and urged courts to "conscientious[ly] use ... powers [granted by] Parliament" to make the legislation work as a whole and "in the spirit intended". ${ }^{165}$ Scott's majority has responded to this request; assuming causation in traditional DOF relationships prevents the unedifying and costly inquiries required by the strict approach and the injustices of depriving $C R H$-type claimants and those making enhancement claims. Consequently, it upholds the equal contribution principle and the principle that PRA disputes "should be resolved as inexpensively, simply, and speedily as is consistent with justice". ${ }^{166}$ Importantly, it does so without rendering the causation requirement meaningless. On this approach, s 15 could be viewed as "ensur[ing] awards are made if there is a [DOF] ... and resulting economic disparity". ${ }^{167}$ The causation requirement's purpose might simply be to weed out exceptional cases where the relationship in no way affected the disparity such as a case where party B's $\$ 50,000$ inheritance directly explains a $\$ 50,000$ disparity. ${ }^{168}$ In such situations, the assumption would be

159 Green, above n 67, at 205.

$160 M v B$, above n 3, at [201].

161 Scott $v$ Williams, above $\mathrm{n}$, at [324] per Arnold J.

162 Reid $v$ Reid [1979] 1 NZLR 572 (CA) at 605.

163 Sian Elias, Chief Justice of New Zealand "Separate Property - Rose v Rose" (speech to Family Court Conference, Wellington, August 2011).

164 At 3.

165 At 16.

166 Property (Relationships) Act, s 1N(d).

167 Law Commission Dividing relationship property - time for change?, above n 10, at [18.66].

168 See Scott v Williams, above n 1, at [323] per Arnold J. See also Part V(C) below. 
rebutted. As later discussed, this article's preference for apportionment further ensures the causation requirement remains meaningful. ${ }^{169}$

\section{Practical workability}

Not only is this "common sense, non-technical view of causation"170 more attractive in policy terms, it is justifiable and practically workable given the Supreme Court's new quantum methodology. Section 15 does not prescribe a methodology. Until $X v X$, judicial approaches had "not exactly been a model of clarity". ${ }^{171}$ The Court of Appeal in $X \vee X$ propounded a methodology premised on the differential between party A's "but for" income and actual income. ${ }^{172}$ Despite warnings that it was not a rote formula, ${ }^{173}$ it "led to a settled period" where many subsequent cases, ${ }^{174}$ including Scott's lower court judgments, employed the methodology. ${ }^{175}$

The Supreme Court in Scott shifted the focus away from $X v X$ 's "but for" emphasis towards a starting point quantum emphasis on relative disparity. Even though s 15 compensates post-separation disparity, under $X v X$ nothing turns on party B's earning capacity and calculations occur "irrespective of the disparity". ${ }^{176}$ Thus, $X \vee X$ 's compensation for detriment or advantage was correctly criticised as "misconceived". 177

This shift in focus at quantum is directly relevant to the correct causation approach. ${ }^{178}$ Strict causation and $X v X^{\prime}$ 's quantum methodology make sense together. ${ }^{179}$ As $X v X$ compensates party A's inability to reach their "but for" income, it is understandable why courts guided by this methodology, required strict "but for" evidence of the extent of loss of earning capacity at causation. However, if we are prepared to reject $X v X^{\prime}$ s methodology then strict causation creates an unnecessary level of analysis and must also be rejected. There is no need to place this significant, potentially unattainable evidential burden on party A if detriment to party A is no longer what is compensated. Rather, we can assume causation in traditional DOF relationships without precise inquiries into the extent of party

169 See Part V(B) below.

170 See similarly Moge v Moge [1992] 3 SCR 813 at [115].

$171 M v B$, above n 3, at [271].

$172 X \vee X$ [Economic disparity], above $\mathrm{n} 8$, at [180] per O'Regan and Ellen France JJ.

173 At [175] per O'Regan and Ellen France JJ.

174 Atkin, above n 2, at 127; and Scott v Williams, above n 1, at [350] per Elias CJ.

175 Williams v Scott [2014] NZFC 7616 at [323]-[344]; and Williams v Scott (HC), above n 130, at [158]-[166].

176 Atkin, above n 2, at 119.

177 Scott $v$ Williams, above n 1, at [347] per Elias CJ. See also Atkin, above n 2, at 119.

178 Scott $v$ Williams, above n 1, at [291] and [293] per Arnold J.

179 At [292] per Arnold J. 
A's loss. Given the jurisdictional hurdle simply requires a causal link, assuming that there is enough of a causal nexus for party A to clear the jurisdictional hurdle is justifiable. ${ }^{180}$ It reflects research and hence the likely situation while avoiding the evidential, and now unnecessary, "difficult[ies] ... of show[ing] loss in the individual case". ${ }^{181}$

\section{B Apportionment}

However, this article argues that the above arguments are most justifiable as a matter of jurisdiction, if apportionment is undertaken at quantum. Here, it departs from the majority and agrees with Scott's minority. Scott's quantum methodology requires "identifying the extent of the disparity resulting from the [DOF]". ${ }^{182}$ If the assumption applies at jurisdiction, the majority's noapportionment approach attributes the entire disparity to the DOF at quantum. ${ }^{183}$

This article's proposal amalgamates the majority's jurisdictional reasoning and the minority's quantum (apportionment) reasoning ("amalgamated approach"). This amalgamation best strikes the correct balance, ensuring s 15's "because of" wording is not unduly restrictive, while also ensuring it is not rendered meaningless. As discussed, because jurisdiction only requires a causal link, jurisdictional causation can safely be assumed in traditional DOF relationships. ${ }^{184}$ The strength of that assumed causal link and the existence of other causes are jurisdictionally irrelevant because the DOF need not be the sole, principal, or even real and substantive, cause of the disparity. Provided the other jurisdictional hurdles are cleared, a causal link entitles party A to some compensation. However when determining quantum, the existence of multiple causes is highly relevant. "[R]elative causal responsibility must be determined"185 as only disparity because of the DOF is compensable and not disparity per se. ${ }^{186}$ By ignoring other causal factors, the majority's approach of attributing the entire disparity to the DOF risks overcompensation contrary to the statutory wording.

A potential criticism of apportionment relates to difficulties in determining the proportion of disparity caused by the DOF compared to other non-compensable causes. A structured method for

180 See similarly Carol J Rogerson "The Causal Connection Test in Spousal Support Law" (1989) 8 Can J Fam L 95 at 132.

181 See similarly Miles "Dealing with Economic Disparity: An Analysis of Section 15 Property (Relationships) Act 1976", above n 15, at 543.

182 Scott $v$ Williams, above n 1, at [326(a)] per Arnold J.

183 At [326(a)], n 420 per Arnold J.

184 See Part V(A)(2) above.

185 Miles "Financial Provision and Property Division on Relationship Breakdown: A Theoretical Analysis of the New Zealand Legislation", above n 98, at 295; de Malmanche $v$ de Malmanche [2002] 2 NZLR 838 (HC) at [166]; and Atkin, above n 2, at 123.

186 Scott $v$ Williams, above $\mathrm{n} 1$, at [384] per O'Regan J. 
making this assessment may well be by reference to each party's "but for" income. This would provide a precise indication of the extent of disparity demonstrably referable to the DOF. ${ }^{187}$ However, such an exercise would require the same type of speculative and costly expert evidence that the working assumption seeks to ameliorate, making the assumption's benefits seem illusory. The only difference would be that this evidential requirement is postponed from causation to quantum.

However, apportionment need not follow such technically precise methods. As O'Regan J noted: "a broad [apportionment] approach ... is appropriate". ${ }^{188}$ Where multiple causes exist: ${ }^{189}$

... [it is not] necessary ... to adduce expert evidence of the extent to which [party A's domestic] ... role ... enhanced [party B's] ... future income and living standards [or restricted party A's]. The Judge ... need[s] to make a broad assessment taking into account the qualifications and career stage of the partners when the relationship began and when [it] ... ended, the period for which the functions were divided, what, in broad terms, the respective functions were and any other relevant matters.

Despite creating additional analysis, apportionment should not be ignored "if a just result is the aim". ${ }^{190}$ Contrary to Arnold J's comments, apportionment is not "incapable of rational resolution". ${ }^{191}$ Judges are capable of, and experienced in, making such assessments similar to those undertaken in contributory negligence. ${ }^{192}$ In fact, certain aspects of Arnold J's judgment are evocative of apportionment. He conceded that personal characteristics could sometimes provide a "partial explanation" of disparity and if so, "it may be that only part of the disparity can fairly be said to result from the [DOF]". ${ }^{193}$ His subsequent no-apportionment approach is inconsistent with these pronouncements.

\section{Rebuttal}

The amalgamated approach is further justified as it provides a better solution to the problematic implications created by the assumption's rebuttable nature. The corollary of the assumption being a rebuttable presumption ${ }^{194}$ is that it imports a reverse burden on party B for rebuttal. ${ }^{195}$ Whether party B's burden is evidential or legal is unclear. A legal burden would be problematic, fitting

187 See generally at [294] per Arnold J.

188 At [386] per O'Regan J.

189 At [386] per O'Regan J (footnote omitted).

190 Atkin, above n 2, at 123.

191 Scott $v$ Williams, above n 1, at [324] per Arnold J and [449]-[450] per William Young J.

192 At [450] per William Young J.

193 At [325] per Arnold J (emphasis added).

194 See Part II(A)(3) above.

195 See similarly Henaghan and others, above n 61, at 1106. 
"uncomfortably within this legislative regime" that simply requires courts "to be satisfied about a state of events which ... exists". ${ }^{196}$ It would also appear incongruous given the well-settled position that party A bears no legal burden. ${ }^{197}$ In fact, Arnold $\mathrm{J}$ cited $X \vee X$ which disclaimed a legal burden on "any party". ${ }^{198}$ Yet, the majority's language suggests the burden "is more than evidential"199 with "little room" allowed for rebuttal. ${ }^{200}$

Even an evidential burden would attract criticism. Given the issue with the strict approach was party A's high evidential burden it would be ironic for the working assumption solution to remove that difficulty for party A by shifting it to party B. Put this way, all the assumption does is shift causation from something party A tried to establish to something party B tries to knock down.

However, this shift is justifiable as it better reflects the usual reality in traditional DOF relationships. After all, before Scott, courts essentially worked from a different presumption: that no causal link existed absent strict evidence of the DOF's impact on earning capacity. ${ }^{201}$ In a choice between presumptions, Scott's assumption (or presumption) is the better choice. The alternative presumption is less attractive in that it unrealistically "presume[s] a model of [relationships] ... in which [partners] ... make independent economic choices and are hence responsible for their own economic positions", rather than acting in the interests of their joint enterprise. ${ }^{202}$

More problematically, the assumption's rebuttable nature casts doubt on its avowed purpose to remove speculative, unedifying and costly evidence previously led. O'Regan J validly queried whether it would truly "reduce the extent to which evidence is adduced by [party B]", noting that one would "expec[t] that attempts will be made to [rebut the assumption]". 203

The majority may respond to O'Regan $\mathrm{J}$ by noting that the high threshold dissuades frivolous rebuttal as only "compelling"204 evidence of causes "clearly independent of the [DOF]" suffice. ${ }^{205}$ However, the majority's no-apportionment approach makes it unclear how strongly party B will be

$196 M v B$, above $\mathrm{n} 3$, at [39].

197 Scott $v$ Williams, above $\mathrm{n}$ 1, at [292] per Arnold J.

$198 X \vee X$ [Economic disparity], above n 8, at [96] (emphasis added), as cited in Scott $v$ Williams, above $\mathrm{n} 1$, at [292], n 374 per Arnold J.

199 See similarly Atkin, above n 2, at 111.

200 See similarly Henaghan and others, above n 61, at 1106.

201 Scott $v$ Williams, above $\mathrm{n}$ 1, at [383] per O'Regan J.

202 Rogerson, above n 180, at 122.

203 Scott $v$ Williams, above $\mathrm{n} 1$, at [382] per O'Regan J.

204 At [294] and [323] per Arnold J (emphasis added).

205 At [204], n 293 per Glazebrook J and [324] per Arnold J. 
dissuaded. The no-apportionment approach incentivises party B to try their utmost to rebut the assumption with the type of strong, yet costly and potentially unedifying, evidence envisaged. If not, party B will have to compensate for the entire disparity.

Conversely under the amalgamated approach, a prudent solicitor could advise party B against rebuttal unless something truly independent of the DOF exists that provides a complete explanation for the disparity. A debilitating illness suffered by party A, a large inheritance received by party B, or situations where significant disparity exists but is lesser than the disparity when the relationship began might provide these complete explanations. ${ }^{206}$ Adducing evidence of causes providing partial explanations of the disparity is futile because jurisdiction is still established provided the DOF has a causal effect. Party B need not fear that they may be forced to overcompensate for the entire disparity where other causal factors exist. In such situations, courts will apportion the causes to determine a fair starting point compensable disparity. ${ }^{207}$ Or more simply, a solicitor may advise party B that the assumption "sends a clear signal" that in traditional DOF relationships, party A is entitled to some compensation. ${ }^{208}$ Therefore party B's efforts are best spent focusing on negotiating a fair quantum settlement, thus avoiding the time, money and stress consumed by litigation.

\section{FRAMING THE WORKING ASSUMPTION}

A remaining issue is whether the majority correctly framed the assumption as arising in relationships conducted along traditional lines. Given "traditional lines" is likely to mean roledivisions where party A undertakes primary responsibility for home-making and childcare and party B for income-earning, ${ }^{209}$ this article agrees with the majority's idea of when the assumption should arise. However, the "traditional lines" and "non-career partner" terminology creates unnecessary confusion. We should simply say that, subject to rebuttal, in relationships where party A has undertaken primary responsibility for domestic duties and party B for income-earning, causation is assumed ("primary responsibility notion"). This framing is justified when the alternatives are considered.

One alternative is to look to different types of relationships - heterosexual or homosexual marriages, de facto relationships, or civil unions - and consider whether the assumption should arise in any, or all, of these relationships. However, such categorisation tells us nothing about the DOF nor how it relates to disparity. Provided a relevant role division exists, the type of relationship is irrelevant especially given that, alongside s 15, the PRA's extension to such relationships was the headline of

206 At [213] per Glazebrook J and [323] per Arnold J.

207 See Part V(B) above.

208 See similarly Law Commission Dividing relationship property - time for change?, above n 10, at [19.24].

209 See Part II(A)(2) above. 
the 2001 reform. ${ }^{210}$ Thus, the "traditional lines" terminology should be eschewed. Although the majority was focusing on traditional role-divisions, that language can create misconceptions that the assumption only arises in the "traditional" heterosexual marriage with a breadwinning husband and housewife.

Another alternative is to consider the different role-divisions undertaken by New Zealand couples and consider whether the assumption should arise in any, or all, of those situations. Based on 2016 data of couples with dependent children, three statistical categories emerge: ${ }^{211}$

- "Unemployed/full-time" (33 per cent): Party A does not undertake paid work. Party B works full-time.

- $\quad$ "Part-time/full-time" (22 per cent): Party A works part-time. Party B works full-time.

- $\quad$ "Full-time/full-time" (45 percent): Party A works full-time. Party B works full-time.

Again, framing the assumption as against these statistical categories is unhelpful. For example, although causation was conceded in Scott, it was accepted to be a traditional DOF relationship. ${ }^{212}$ Scott was the primary caregiver and often worked part-time. Williams worked full-time throughout. This might incline us to say that the assumption arises in part-time/full-time relationships. But that misses the point. The reason why the assumption would arise is not by virtue of there being a parttime/full-time relationship, but because Scott worked part-time so that she could undertake primary responsibility for domestic duties which restricted her income-earning capacity and freed Williams to enhance his.

This point is most pertinently illustrated when considering full-time/full-time relationships. Statistically, this is the most common role-division. ${ }^{213}$ However, statistical categorisations are oversimplistic for causation purposes. Querying whether the assumption should arise in full-time/full-time relationships is not the right question to ask. An instinctive answer is that it should not arise. Arguing that party A "freed up" party B to focus on their career seems unconvincing given party A, like party B, worked full-time. Similarly, one might query how party A's earning capacity was restricted if they too continued full-time work. This thinking has influenced past cases where claimants who worked full-time have found establishing causation difficult. ${ }^{214}$

210 Green, above $\mathrm{n} 67$, at 10 .

211 Law Commission Relationships and Families in Contemporary New Zealand, above n 65, at 39.

212 Scott $v$ Williams, above $\mathrm{n}$ 1, at [299] per Arnold J.

213 Law Commission Relationships and Families in Contemporary New Zealand, above n 65, at 39.

214 See for example JA v SNA [Economic disparity] [2008] NZFLR 297 (HC); Varney, above n 16, at 42; and Heidi Gray "Inequality in Equal Division: Embracing a Canadian Approach to Remedy Economic Inequality Upon Relationship Breakdown" (LLB (Hons) Dissertation, University of Otago, 2009) at 14. 
However, instinctive answers hide the various permutations within these statistical categories. A full-time/full-time relationship could be one where both parties continued "to enjoy full careers unimpeded, or at least equally impeded by domestic responsibilities". ${ }^{215}$ In such situations, it is difficult to argue the assumption should arise. But full-time/full-time relationships could also be ones where party A has a "double burden" by working full-time and also undertaking "a far greater portion of domestic functions" than party B. ${ }^{216}$ In such situations, party A does free party B to specialise in money-making. It may not be to the same extent as if party A did not work at all, but it is still more so than if the parties equally shared domestic duties. Similarly, party A could have worked full-time but sacrificed their lucrative, yet inflexible career, with inconsistent hours, in favour of a less lucrative, 9-5 job to ensure they could undertake childcare at night. Meanwhile, party B continued in the same lucrative, yet inflexible career, often away for whole days at a time. ${ }^{217}$ In such situations, the DOF has restricted party A's income-earning capacity as it is easy to get left behind in professional careers after protracted absences. ${ }^{218}$ It also allowed party B to continue to cultivate their earning capacity in a lucrative field unburdened by domestic duties.

What this analysis illustrates is that the focus ought to be on whether party A undertook primary responsibility for domestic activities allowing party B to focus on career tasks unimpeded, or less impeded, than if party A did not undertake these domestic responsibilities. Focusing on whether party A was unemployed, worked part-time, or full-time is unhelpful. To take the full-time/full-time example: a proposition that the assumption arises in all full-time/full-time relationships is overbroad as that includes situations where both parties worked full-time, unimpeded, or equally impeded by domestic activities such that no causality between the DOF and disparity exists. However, to say it never arises in full-time/full-time relationships fails to reflect the fact that in many such relationships party A may "declin[e] a promotion, refus[e] a transfer ... or otherwise curtai[l] employment opportunities" in the interests of the family, thereby suffering disadvantage while enhancing party B's earning capacity. ${ }^{219}$

A misplaced focus can lead to the type of unattractive reasoning seen in JA $v$ SNA [Economic disparity] where both parties entered the relationship as trainee teachers and worked full-time throughout. ${ }^{220}$ At separation, SNA was a principal while JA was still a teacher earning considerably

215 Rogerson, above n 180, at 122.

216 Varney, above n 16, at 42.

217 This scenario is loosely based on Monks v Monks [2006] NZFLR 161 (HC).

218 See for example Nicole Ashby "Absent from the Top - A critical analysis of women's underrepresentation in New Zealand's legal profession" [2017] 1 NZWLJ 80 at 87.

219 Moge v Moge, above n 170, at [82].

$220 \mathrm{JA} v$ SNA [Economic disparity], above n 214, at [3]. 
less. ${ }^{221}$ Since child-rearing and economic sacrifices are stereotypically expected from mothers, the DOF's detrimental impact on JA's earning capacity was rejected. ${ }^{222}$ The High Court accepted the Family Court's reasoning ${ }^{223}$ that it was "inevitable [JA] ... would play a larger part in the children's lives"224 and that "[I]ike many other women, she juggled her career aspirations with competing calls on her time". ${ }^{225}$ Economic advantage to SNA was also ignored. To that extent, Scott's "non-career partner" terminology should be eschewed, as it prevents the assumption arising in a JA-type situation where party A had a career but undertook primary domestic responsibility to their disadvantage and party B's advantage.

This primary responsibility notion does not create evidential difficulties or require party A to positively prove that they undertook primary responsibility for domestic duties. The approach is summarised below: 226

[A]n exact tally of debits and credits for each day of the ... [relationship is not required]. ... It is clear that certain things must be done to maintain a family. Income must be earned. Food must be bought and prepared. Children must be cared for. ... [I]t will suffice if the parties tell the ... [court] in a general way what each did. That will allow the ... [court] very quickly to get an accurate picture of the sacrifices, contributions and advantages relevant to determining compensation[.]

The court can then assess whether party A undertook primary responsibility for domestic duties. If so, causation is assumed, subject to rebuttal, and apportionment at quantum.

Some residual injustices in terms of relativity may remain. An assumption framed to focus on the primary responsibility notion assumes causation in situations where party A undertook no paid work and was fully devoted to domestic activities, in situations where party A split time between the two and even in situations where party A worked full-time but still undertook a greater proportion of domestic duties. The causal link is prima facie strongest in the first situation and weakest in the last. If the amalgamated approach is adopted, the apportionment exercise will ensure these differences are recognised when courts determine compensable disparity. Prima facie, in the first situation a high proportion, if not all, of the disparity will be apportioned to the DOF. In the last situation, perhaps only a small proportion of the disparity will be apportioned to the DOF given the disadvantage to

221 At [3].

222 Varney, above n 16, at 42; and Gray, above n 214, at 14.

223 JA v SNA [Economic disparity], above n 214, at [14]

224 At [12] (emphasis added).

225 At [13], citing SNA v JA FC Hamilton FAM-2003-019-588, 29 March 2007 at [94] (emphasis added).

226 Moge v Moge, above n 170, at [116]. 
party A, or advantage to party B, is less pronounced than unemployed/full-time situations where party A devoted all their time to domestic duties.

Another uncertainty is whether the assumption only arises in long-duration relationships, with children and which were entered into early in adult life. These factors are mentioned throughout Scott's judgments, no doubt influenced by Scott and Williams' 26-year two-child relationship. ${ }^{227}$ William Young J's conceptualisation of the majority's assumption includes long-duration relationships as a prerequisite. ${ }^{228}$ Glazebrook J and Elias CJ tended to emphasise this factor, ${ }^{229}$ albeit expressing broad support with Arnold J's reasoning. ${ }^{230}$ Arnold J does not consider it a prerequisite. For him, a longduration relationship with children and entered into early in adult life simply means the assumption would be particularly strong, and rebuttal would be highly unusual, compared to shorter-duration, childless relationships entered later in life. ${ }^{231}$

It is understandable why long-duration relationships could be singled out because "the longer the ... [relationship], the greater the probability of economic integration between the [partners]" in their joint enterprise. ${ }^{232}$ However to avoid disputes as to what qualifies as sufficiently long, and given Arnold J provided the assumption's fullest exposition, it is safe to assume causation whatever the relationship's length. Similarly, a childless relationship entered into later in life should not in itself disentitle a claimant from the assumption's benefits. Provided party A undertook primary responsibility for other domestic duties the assumption should still arise. However, the fewer the childcare duties or the shorter the relationship, the easier it will be for party B to rebut the assumption completely or to argue for greater apportionment on the amalgamated approach. Similarly, in relationships entered later in life, which are becoming increasingly common, ${ }^{233}$ party B is more able to whittle down the assumed causal link by arguing that they entered the relationship having already established the high earning capacity they continue to boast of post-separation. ${ }^{234}$

The vast diversity of relationships makes it difficult to set adequately specific prerequisites to capture relationships where the assumption should arise, while excluding those where it should not. The better approach is to set more general, fundamental requirements leaving rebuttal and apportionment exercises to ensure the strength of the causal link is fairly reflected at quantum. This

227 Scott $v$ Williams, above n 1, at [6] per Glazebrook J.

228 At [444] per William Young J.

229 At [204] per Glazebrook J and [345] per Elias CJ.

230 At [203] and [205] per Glazebrook J and [356] per Elias CJ.

231 At [323] per Arnold J.

232 Rogerson, above n 180, at 114.

233 Law Commission Relationships and Families in Contemporary New Zealand, above n 65, at 15.

234 See Scott $v$ Williams, above n 1, at [325] per Arnold J. 
is also justified because Scott does not discuss what occurs if the assumption does not arise. Is party A not to have a claim? Or is the strict approach to be applied? That would be incongruous given the strong criticism of the strict approach's speculative, costly and unedifying evidential burden. The more claimants that are able to utilise the assumption's benefits of removing this evidential burden, the better. A broad assumption formulation, with a single prerequisite of party A undertaking primary responsibility for domestic duties and party B for income-earning, facilitates this outcome without losing its justifiable, theoretical peg. After all, research and common sense indicate that where party A undertakes primary responsibility for domestic duties and party B for income-earning, the assumption is not unfounded. ${ }^{235}$ The relationship's length, when it was entered into and other relevant factors simply enhance or reduce the strength of the assumed causal link.

\section{CONCLUSION}

Section 15's laudable rationale has not translated into practical success. A strict, and now unnecessary, causation approach has been a key barrier. Thus Scott's working assumption, which eschews the strict causation approach, is a positive development in terms of satisfying jurisdiction. However, Scott's majority was wrong to reject apportionment at quantum as it risks overcompensating party A for disparity not attributable to the DOF which is contrary to the statutory wording. Adopting this article's amalgamated approach better assists in striking the correct balance between s 15's broad policy rationale and stricter "because of" wording. Furthermore, Scott's "traditional lines" and "noncareer partner" terminology should be avoided in framing the assumption.

Thus, the ideal proposition is: at jurisdiction, causation is assumed in relationships where party A has undertaken primary responsibility for domestic duties and party B for income-earning regardless of whether party A also undertook paid employment. If truly independent causes provide a complete explanation for the disparity, the assumption will be rebutted. Otherwise, the existence of other causes in addition to the DOF will be appropriately reflected through a broad apportionment exercise at quantum. 
